\title{
USING ALTERNATIVE STRATEGY FOR IMPLEMENTING SIMPLE INVESTIGATIVE ACTIVITIES TO LEARN CHEMISTRY IN THE CLASSROOM
}

\author{
Solange W. Locatelli \\ Federal University of $A B C$, Brazil
}

\begin{abstract}
Considering the diversity of activities in the classroom is very important, with a view to providing opportunities for students to learn chemistry. In this sense, this article aims to bring some myths and concepts that underlie the inquiry-based learning (IBL), as well as to present an activity proposal to be used in the classroom, considering an opportunity to work the investigative aspect in science, with the use of simple and easily accessible materials. It is considered fruitful to bring these reflections into a context of teacher education, in which metacognitive thinking should be part of pedagogical practice for better learning in science and in general.
\end{abstract}

Keywords: teacher training, chemistry education, inquiry-based learning

\section{Introduction}

It is very common to use hands-on experiments in order to learn chemistry, which we know is important, such as manipulating substances, mixing them, observing the chemical reaction happening, etc. However, should all investigative activities necessarily involve the use of laboratory materials? The purpose of this article is, first, to reflect on what investigative classes are, some myths and their foundations. Next, there is a possibility of a strategy to be used in the classroom, with the use of few materials required for the class.

\section{Some Concepts and Myths about Investigative Classes}

The diversification of the use of strategies in the classroom is considered essential for student learning, sometimes the question remains, but what and how to teach chemical concepts so that students effectively understand and learn? There are many didactic approaches to be used, but research has revealed great potential of inquiry-based learning (IBL) in the classroom, contributing to scientific literacy (Campos \& Sena, 2020; Franco \& Munford, 2020); rather than more expository approaches, those in which the teacher exposes the content, without much or no discussion among learners.

It is considered, then, that in the first case (IBL) students will be able to act as protagonists and will be adequately supported (Lazonder \& Harmsen, 2016), in the specific case of science, they will have the opportunity to get closer to what it is to do science, know scientific concepts and learn about science.

Although there are many definitions about inquiry-based learning, we can consider what the authors Zômpero and Laburú (2011) observed when analyzing numerous works in this perspective. Some precepts are common among these various researchers, which are: "there is a problem to be analyzed, the emission of hypotheses, a planning for carrying out the investigative process, aiming at obtaining new information, the interpretation of this new information and subsequent communication of the same" (p. 74 and 75, our translation). 
Still on the classes in this investigative perspective, Carvalho (2017) adds that the teaching material provided should include a contextualized question, and based on the students' previous ideas, hypotheses will be raised and tested in order to resolve the issue presented, with resumption, construction and reconstruction of concepts. With these definitions, it may seem like something very difficult to do in the classroom, and what we report next is the opposite, it is possible and feasible.

Figure 1 illustrates the steps of the investigative activities developed and presented as follows:

\section{Figure 1}

Overview of Some Possible Elements of a Class from an Investigative Perspective

\section{ENGAGEMENT -Student engagement for the task}

\section{PROBLEM - It starts with a question-problem - time for raising hypotheses}

\section{HYPOTHESES - Students plan how they will carry out the investigation, testing} hypotheses, obtaining new information

4. INTERPRETATION and SIYSTEMATZATION - Interpretation of new information, with interaction between students, in which scientific concepts are discussed and (re) constructed

\section{COMMUNICATION - Communication of ideas, taking note of collective production}

Figure 1 shows, in a simplified way, some possible constituent elements of an investigative class. Next, we will deal with three myths or misunderstandings that we consider important to reflect on this didactic approach.

According to Munford and Lima (2007), we can consider at least three myths or misunderstandings about IBL, which we consider important to reflect here in this article, as well as discuss with teachers during in-service courses offered to them. We started from the three myths listed by Munford and Lima (2007) and we proposed three questions, as seen in the table 1:

\section{Table 1}

Myths or Misunderstandings about IBL

\section{Myth or misunderstanding}

\begin{tabular}{ll}
\hline 1 & $\begin{array}{l}\text { Should the inquiry-based learning be a totally open teaching, where students necessarily } \\
\text { choose the question to be investigated, elaborate the work plan and conclusions? }\end{array}$ \\
\hline 2 & $\begin{array}{l}\text { Should the inquiry-based learning be used during all the time, for studying all topis in chemistry } \\
\text { education, for instance? }\end{array}$ \\
\hline 3 & $\begin{array}{l}\text { Should the inquiry-based learning approach only be carried out with practical or experimental } \\
\text { activities? }\end{array}$ \\
\hline
\end{tabular}


About myth (1), table 1, it is important to consider the 5 degrees pointed out by Carvalho et al. (2010), as table 2:

Table 2

Freedom Degree - Teacher (T) and Students (S), Considering Experimental Activities

\begin{tabular}{llllll}
\hline & Degree 1 & Degree 2 & Degree 3 & Degree 4 & Degree 5 \\
Problem & $\mathrm{T}$ & $\mathrm{T}$ & $\mathrm{T}$ & $\mathrm{T}$ & $\mathrm{S}$ \\
\hline Hypothesis & $\mathrm{T}$ & $\mathrm{T} / \mathrm{S}$ & $\mathrm{T} / \mathrm{S}$ & $\mathrm{S}$ & $\mathrm{S}$ \\
\hline Work plan & $\mathrm{T}$ & $\mathrm{T} / \mathrm{S}$ & $\mathrm{S} / \mathrm{T}$ & $\mathrm{S}$ & $\mathrm{S}$ \\
\hline Obtaining data & $\mathrm{S}$ & $\mathrm{S}$ & $\mathrm{S}$ & $\mathrm{S}$ & $\mathrm{S}$ \\
\hline Conclusions & $\mathrm{T}$ & $\mathrm{S} / \mathrm{T} /$ Class & $\mathrm{S} / \mathrm{T} /$ Class & $\mathrm{S} / \mathrm{T} /$ Class & S/T/Class \\
\hline
\end{tabular}

Note: Adapted from Carvalho et al, 2010, p. 55

As you move to the right in table 2, the investigative class has more opening, more focused on students and, actually there is no right or wrong, it depends on many factors, such as the students' age or educational level, among others, and it is important that, little by little, greater openness is allowed to them, so they will develop more and more cognitive/ metacognitive skills, acquiring autonomy to learn how to learn.

With respect to myth (2), teacher should use several strategies, considering the IBL, to work on some themes. Firstly because of time, since it takes time to develop a didactic sequence in this IBL perspective, and also because of the adequacy of the proposal. For example, in the discussion about the use or not of nuclear energy in a country, the debate could be used, besides other strategies to be considered to learn science could be games, study of articles, solving exercises, seminars, concept maps, movies, portfolios, drawings, even lectures to systematize content, among many others.

Finally, regarding to myth (3), an experimental or practical activity does not necessarily have the elements of an investigative activity and sometimes an activity that is not practical may include more investigative character (Munford and Lima, 2007). In experimental activities, it is very common for students to have a well-defined script to follow, completing steps; for example, mixing two liquids $\mathrm{A}$ and $\mathrm{B}$ and observing what happens, now writing down their observations, etc., students only have to follow order, or else, often the goal is just to confirm something students already know, some theory, etc. These types of activities have a very restricted investigative aspect, as the students only need to "follow" the script.

On the other hand, an example of activity that is not practical, but has an investigative character will be presented below, as sometimes teacher does not have enough time to develop the activity in the laboratory or, still, does not have the necessary apparatus in chemistry, for example, glassware, chemical reagents, among others. So balancing classroom strategies should be a good way to teach.

Numerous possibilities of activities could be done in the classroom from an investigative perspective, but an example already carried out is presented below, with favorable results for the students' chemistry learning, with the use of simple materials and without the need of laboratory use. 


\section{Investigative Activity Using a Figure to Learn Heat Concept}

Here, it was called "alternative strategy", because it is an investigative activity that can be carried out in the classroom, without the use of substances or devices, which would not be a problem if it were, but it is considered important situations in which the teacher, due to a matter of time or lack of structure, cannot take students to the laboratory and, despite this, can provide opportunities to experience the didactic approach of inquirybased learning.

Mortimer and Amaral (1998) proposed a simple experiment to discuss with students' concepts such as heat and temperature, which are fundamental to advance in the discussions on thermochemistry, they called the activity "conditions for water to boil", p.34. The authors suggested doing the activity with the students in the laboratory, for example, which is very interesting, but we suggest that, if this is not possible that the discussion be carried out in the classroom, from an investigative perspective, our proposal is here. The idea of this activity is to reflect with the students "that there is only heat transfer when there is a difference in temperature between two systems" (p.34). The proposed scheme is shown in Figure 2:

\section{Figure 2}

System Proposed, Containing Water Both Inside the Beaker and in the Test Tube

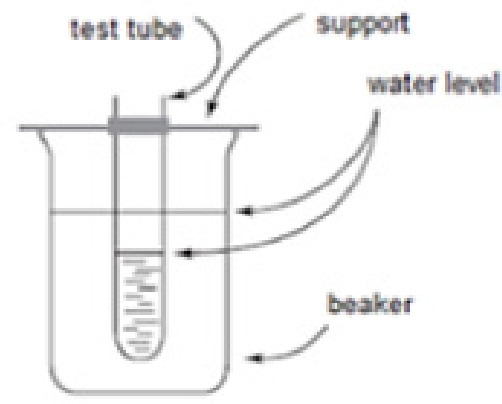

Note: (Adapted form Mortimer and Amaral, 1998, p.34)

As a requirement of an investigative class, and considering a pre-existing context of the subject with students, the teacher could present figure 2, together with the following question to students who, preferably, should be organized in pairs, precisely to generate discussion and raising hypotheses:

One beaker and a test tube contain water in the liquid state (figure 1). As the system warms up, the water inside the beaker will boil. The water in the test tube:

a) will not boil;

b) will boil at the same time as the water of the beaker

c) will boil some time later (Locatelli, 2018, p. 20)

Students will have time for discussion in pairs and then will externalize their previous ideas, which is essential for building knowledge from them, and all responses are welcome in this strategy. This is because when rethinking previous ideas, students evoke 
metacognitive ${ }^{1}$ thinking, with the possibility of awareness and monitoring of cognitive processes, important and associated metacognitive aspects at this stage of assessment and, thus, with the possibility of contributing to the self-regulation of processes cognitive factors involved in the activity. Collectively, the students conclude that alternative (a) is the correct one, moment of systematization and communication of results, it could be registered on the blackboard, for example, or by electronic means.

Locatelli (2018) used this strategy with undergraduates and observed that 1/67 of the students got the question right, which made it possible to collectively build the concepts from the error shown by the vast majority of students. This points to one more important point, according to Santana, Locatelli and Franzolin (2017), considering the error as "something inherent in the investigation process and enabling new investigative activities" (p. 1069). Essential to reinforce here, that the error is part of the process of (re) construction of concepts, its occurrence being something very favorable to learning, going against common conceptions that 'we should not make mistakes', here, on the contrary, error is considered an ally, as it helps us to redirect students' thinking, ideas, constructions of scientific concepts.

Thus, in this context, the importance of teacher mediation throughout the process is highlighted, redirecting when necessary for student learning. Here, it is worth commenting that the teacher must lead in a way to help their students achieve their goals, allowing them to (re)think, so that they could move forward, autonomously, but without receiving ready answers, showing a collective construction and not centered on the teacher, who is not the holder of knowledge. In the same direction, Lazonder and Harmsen (2016), who investigated 72 studies on this topic, found the role of teacher guidance as crucial for the success of the inquiry-based learning approach in the learning process.

\section{Final Considerations}

The theoretical framework about inquiry-based learning is very broad and complex, the intention was to bring here just a few elements for discussion, especially considering the training of teachers.

It is not defended here that investigative activities are always carried out without the use of the laboratory or practical activity, instead considering it as a possibility, feasible and with good results to be considered by the teacher in cases where time and structure could be impeding to the didactic approach. The ideal would be to consider a balance of activities within a plan, contemplating both practical activities in the laboratory and in the classroom.

It is essential to provide opportunities for students to express their previous ideas and perceive the error as a fruitful opportunity for learning, enabling the evocation of metacognitive thinking, which, with the mediation of teachers, can generate good learning.

\section{References}

Campos, J. G., \& Sena, D. R. C. (2020). Aspectos teóricos sobre o ensino de ciências por investigação [Theoretical aspects of science education by investigation]. Ensino em Revista, 27, 14671491.

$1 \quad$ According to Schraw (1998) metacognition involves, either being the knowledge about knowledge and self-regulation of the cognitive process. 
Carvalho, A. M. P. (2017). O ensino de ciências e a proposição de sequências de ensino investigativas [Science Education and the proposition of investigative teaching sequences]. In: Carvalho, A. M. P. (Org.), Ensino de Ciências por investigação: Condições para implementação em sala de aula (pp. 1-20). Cengage Learning.

Carvalho, A. M. P., Ricardo, E. C., Sasseron, L. H., Abib, M. L. V. S., \& Pietrocola, M. (2010). Ensino de Física [Physics education]. Cengage Learning.

Franco, L. G., \& Munford, D. (2020). Inquiry-based science teaching under construction: Possibilities of articulations between conceptual, epistemic and social domains within scientific knowledge in the classroom. Revista Brasileira De Pesquisa Em Educação Em Ciências, 20, 687-719. https://periodicos.ufmg.br/index.php/rbpec/article/view/19262/19573

Lazonder, A. W., \& Harmsen, R. (2016). Meta-Analysis of inquiry-based learning: Effects of guidance. Review of Educational Research, 86(3), 681-718. https://doi.org/10.3102/0034654315627366

Locatelli, S. W. (2018). Information and communication technology (ICT) as a metacognitive strategy for reconstructing science concepts. Lumat: Research and Practice in Math, Science and Technology Education, 3, 15-27. http://journals.helsinki.fi/lumatb/article/view/1144

Mortimer, E. F., \& Amaral, L. O. (1998). Quanto mais quente melhor - calor e temperatura no ensino de termoquímica [The hotter the better - heat and temperature in thermochemistry teaching]. Química nova na escola, 7, 30-34. http://qnesc.sbq.org.br/online/qnesc07/aluno.pdf

Munford, D., \& Lima, M. E. C. C. (2007). Ensinar ciências por investigação: em quê estamos de acordo? [Teaching science by inquiry: What do we agree on?]. Ensaio Pesquisa em Educação em Ciências, 9(1), 89-111. https://www.scielo.br/j/epec/a/ZfTN4WwscpKqvwZ $\mathrm{dxcsT} 84 \mathrm{~s} /$ ?lang $=$ pt\&format $=$ pdf

Santana, R. S., Locatelli, S. W., \& Franzolin, F. (2017). Possibilidades e desafios na implementação de atividades investigativas: particularidades docentes [Possibilities and challenges in the implementation of investigative activities: teaching particularities]. Enseñanza de las ciencias: revista de investigación y experiencias didácticas, Extra, (0), 1065-1070. https:// raco.cat/index.php/Ensenanza/article/view/335615/426427

Schraw, G. (1998). Promoting general metacognitive awareness. Instructional Science, 26(1-2), 113-125. https://doi.org/10.1023/A:1003044231033

Zômpero, A. F., \& Laburú, C. E. (2011). Atividades investigativas no ensino de ciências: aspectos históricos e diferentes abordagens [Investigative activities in Science Education: Historical aspects and different approaches]. Ensaio: Pesquisa em Educação em Ciências, 13(3), 6780. https://www.scielo.br/j/epec/a/LQnxWqSrmzNsrRzHh3KJYbQ/?lang=pt\&format=pdf

Received 10 October 2021; Accepted 22 December 2021

Cite as: Locatelli, W. S. (2021). Using alternative strategy for implementing simple investigative activities to learn chemistry in the classroom. Gamtamokslinis ugdymas / Natural Science Education, 18(2), 87-92. https://doi.org/10.48127/gu-nse/21.18.87

\section{\begin{tabular}{lll}
\hline & $\quad$ \\
& Solange W. Locatelli
\end{tabular}}

$\mathrm{PhD}$, Center for Natural and Human Sciences, Federal University of ABC, Av. dos Estados, 5001 - Bangú, Santo André - SP, 09210-580, Brazil.

E-mail: solange.locatelli@ufabc.edu.br

ORCID: https://orcid.org/0000-0002-7639-6772 